\title{
SOME ISSUES REGARDING THE CALIBRATION OF THE TERRESTRIAL LASER SCANNER LEICA SCANSTATION C10
}

\author{
Urtè Antanavičiūtė ${ }^{1}$, Romuald Obuchovski ${ }^{2}$, Eimuntas Kazimieras Paršeliūnas ${ }^{3}$, \\ M. G. Darius Popovas ${ }^{4}$, Dominykas Šlikas ${ }^{5}$ \\ Vilnius Gediminas Technical University, Sauletekio al. 11, LT-10223 Vilnius, Lithuania \\ E-mails: ${ }^{1}$ urtean@gmail.com; ${ }^{2}$ romuald.obuchovski@vgtu.lt; ${ }^{3}$ eimis@vgtu.lt; \\ ${ }^{4}$ darius.popovas@vgtu.lt; ${ }^{5}$ dominykas.slikas@vgtu.lt (corresponding author) \\ Received 28 August 2013; accepted 18 September 2013
}

\begin{abstract}
Some issues regarding the calibration results pertaining to the ground-based laser scanner Leica Scanstation C10 are presented and analysed. The calibration was carried out at Kyviškès Calibration Baseline (Jokela et al. 2002) and the special cyclic error detection baseline at the Research Institute of Geodesy of Vilnius Gediminas Technical University. The instrument was calibrated at 20, 100, 180, 200 and $260 \mathrm{~m}$ distances at Kyviškès Calibration Baseline and the indoors baseline from 1 to $15 \mathrm{~m}$ with continuous $1 \mathrm{~m}$ interval. The special procedure of indirect measurements was suggested to estimate errors of scanner measurements. During this procedure, the positions of the scanstation varied from the calibration baseline pillars to the standard tripods creating triangles of different shapes. The distances obtained by scanning targets placed on the calibration baseline pillars were compared with baseline standard distances. Suggested improvements in the calibration technology could be used for verification and calibration of terrestrial laser scanstations at the calibration baselines.
\end{abstract}

Keywords: terrestrial laser scanner, calibration, calibration baseline, Leica Scanstation C10.

Reference to this paper should be made as follows: Antanavičiūtè, U.; Obuchovski, R.; Paršeliūnas, E. K.; Popovas, M. G. D.; Šlikas, D. 2013. Some issues regarding the calibration of the terrestrial laser scanner Leica Scanstation C10, Geodesy and Cartography 39(3): 138-143.

\section{Introduction}

Terrestrial 3D laser scanners (TLS) - a new class of survey instruments - have become popular and are increasingly used in providing as-built and modelling data in various applications, including land surveying, archaeological studies, architecture, bridge structures, and highway surveys. These scanners could measure thousands of data points (distance, angle, and reflected return signal power) per second and generate a very detailed "point cloud" data set. In addition, these measurements are performed much faster than traditional geodetic surveys in most cases; therefore, terrestrial laser scanning has become an additional surveying technique in the geodesy over the last several years. However, in contrast to traditional geodetic instruments (e.g. total stations, levels, Global Navigation Satellite Systems), accuracies and the systematic errors of most of the available laser scanners are not well-known. An investigation and analysis are essential to use terrestrial laser scanners for high precision applications (e.g. engineering surveying). In order to minimise the systematic influence of the instrumental errors, scanners have to be calibrated and observations have to be corrected on the basis of the calibration parameters (Ingensand 2006). The standardised calibration routines exist for the traditional geodetic and photogrammetric instruments. In the context of TLS, the reliable accuracy assessment is rather complicated due to the fact that laser scanners are constructed in a way completely different from the traditional survey equipment. (Pfeifer, Briese 2007). The accuracy specifications given by laser scanner producers in their publications and pamphlets are not comparable. Experience shows that the given accuracy parameters should not be trusted in some instances; besides, accuracy of these instruments - which are built in small series - varies from instrument to instrument and depends on individual calibration. Much work has been done on point-based 
TLS calibration by exploiting their similarities with theodolites or a total station (Parian, Grün 2005; Lichti, Franke 2005; Lichti, Licht 2006; Lichti 2007; Reshetyuk 2006). Self-calibration approaches have recently been investigated by a number of researchers and can be categorised according to the type of targeting. Two types are reported: signalised point targets and planar features. The common thread between both approaches is the collection of a highly redundant set of spherical observations (range, horizontal direction and elevation angle) from different locations in a strong geometric configuration. (Bae, Lichti 2007; Dorninger et al. 2008; Schneider 2009). The application of mentioned procedures requires a laboratory or a calibration room with known geometrical parameters of targets or planar features. The mentioned calibration procedures use the $3 \mathrm{D}$ coordinates of the measured points; however, the laser scanners actually measure the ranges, vertical and horizontal angles (Pfennigbauer, Ullrich 2010). Therefore, it is important to evaluate each measured parameter separately (Chow et al. 2010).

Some work has been done in distance measurement accuracy evaluation (Salo et al. 2008; Cheok et al. 2007) with the following indication that the accuracy depends on many factors such as scanner model, range measuring method, target properties and etc. Angle measurement accuracy tests indicate that the angle measurement accuracy (especially vertical one) depends on the design of a laser beam deflecting unit (Schneider, Schwalbe 2008; Reshetyuk 2009, 2010).

It is important to point out that no standard measure of the scanner performance and method for its evaluation exists (Lichti 2010). The method proposed by the authors of this paper allows evaluating the distance and angle measurement accuracies under real environmental conditions. Additionally, the proposed method does not require a special calibration laboratory; consequently, a standard geodetic baseline could be used.

\section{Calibration of the distance measuring device of the terrestrial laser scanner at the cyclic error determination baseline}

The calibration of the distance measuring device of the terrestrial laser scanner Leica Scanstation C10 was performed using the cyclic error determination baseline at the Calibration Laboratory of the Research Institute of Geodesy of Vilnius Gediminas Technical University (Jokela et al. 2002; Buga et al. 2008, 2011). The cyclic

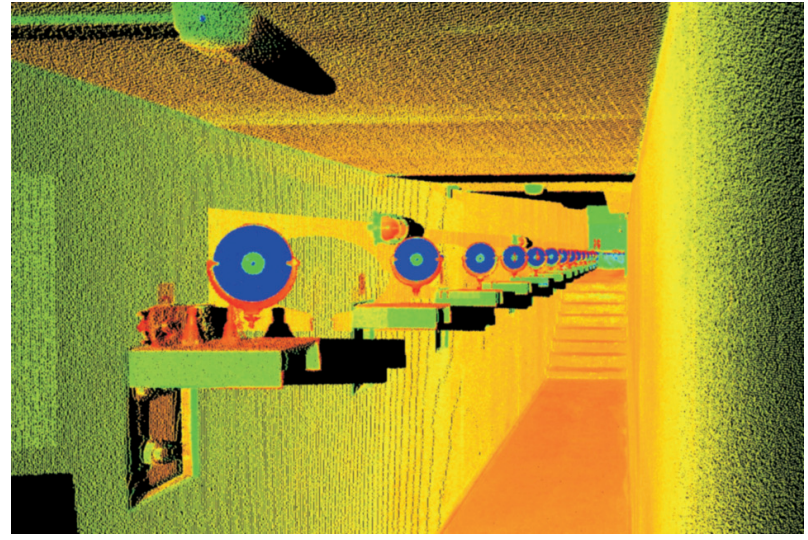

Fig. 1. The cyclic error determination baseline mounts with targets

error determination baseline consists of 16 points, distances between which are approx. 1 metre. During the calibration procedure, the terrestrial laser scanner was force-centred at the first mount and distance measurements were performed to the force-centred targets (6 inches in diameter) positioned on the other mount (Fig. 1).

The point cloud of the each scanned target consists of approx. 39000 points. From these point clouds, the coordinates of the centres of targets were determined using Cyclone software by Leica Ltd. As usual, distances between the scanner and targets were calculated using the formula:

$$
S=\sqrt{\left(X_{t}-X_{s}\right)^{2}+\left(Y_{t}-Y_{s}\right)^{2}},
$$

where $X_{t}$ and $Y_{t}$ - coordinates of the target centre, $X_{s}$ and $Y_{s}$ - coordinates of the scanner.

Calibration parameters of the distance measuring device of the laser scanner were evaluated by comparing the calculated distances with known standard distances. Further data handling and calculations were performed using the standard methodology of the numerical data processing of the calibration results (Putrimas 2010). The final results are presented in Table 1.

Table 1 indicates that systematic errors are relatively small (less than $1.3 \mathrm{~mm}$ ) in short distance measurements. These errors are slightly greater for short distance (up to 3 metres) measurements.

Systematic distance measurement errors are shown in Figure 2.

The constant $R$ of the terrestrial laser scanner was calculated using all systematic errors of the measured distances and is equal to $-0.4 \mathrm{~mm}$. Figure 2 shows that systematic error changes from $-1.3 \mathrm{~mm}$ to $+0.4 \mathrm{~mm}$. 
Table 1. Final results pertaining to calibration parameters of the distance measuring device of the laser scanner based on calibration at the cyclic error determination baseline

\begin{tabular}{|c|c|c|c|c|c|}
\hline $\begin{array}{c}\text { Segment } \\
\text { number }\end{array}$ & $\begin{array}{c}\text { Standard distance, } \\
\mathrm{m}\end{array}$ & $\begin{array}{c}\text { Mean measured } \\
\text { distance, } \mathrm{m}\end{array}$ & $\begin{array}{c}\text { Systematic error } \\
\text { of distances, } \mathrm{mm}\end{array}$ & $\begin{array}{c}\text { Standard deviation of } \\
\text { systematic error, mm }\end{array}$ & $\begin{array}{c}\text { Standard uncertainty } \\
\text { of mean systematic } \\
\text { error value, mm }\end{array}$ \\
\hline 1 & 0.9993 & 1.0005 & -1.2 & 0.4 & 0.1 \\
\hline 2 & 2.0000 & 2.0011 & -1.1 & 0.4 & 0.1 \\
\hline 3 & 3.0006 & 3.0019 & -1.3 & 0.1 & 0.0 \\
\hline 4 & 4.0007 & 4.0014 & -0.7 & 0.5 & 0.1 \\
\hline 5 & 4.9990 & 4.9986 & +0.4 & 0.3 & 0.1 \\
\hline 6 & 5.9981 & 5.9987 & -0.6 & 0.3 & 0.1 \\
\hline 7 & 6.9995 & 7.0004 & -0.9 & 0.2 & 0.1 \\
\hline 8 & 7.9967 & 7.9970 & -0.3 & 0.5 & 0.2 \\
\hline 9 & 8.9990 & 8.9993 & -0.3 & 0.2 & 0.1 \\
\hline 10 & 9.9999 & 10.0002 & -0.3 & 0.2 & 0.1 \\
\hline 11 & 10.9976 & 10.9981 & -0.5 & 0.2 & 0.1 \\
\hline 12 & 11.9995 & 11.9999 & -0.4 & 0.1 & 0.1 \\
\hline 13 & 12.9980 & 12.9980 & 0.0 & 0.9 & 0.3 \\
\hline 14 & 13.9992 & 13.9989 & +0.3 & & \\
\hline 15 & 15.0038 & 15.0040 & -0.2 & & \\
\hline
\end{tabular}

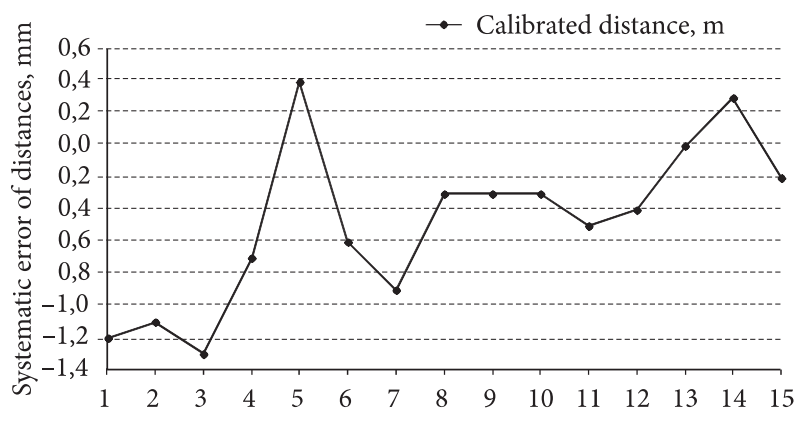

Fig. 2. Graphical representation of systematic errors of the terrestrial laser scanner distance measuring device based on the calibration at the cyclic error determination baseline

\section{Calibration of the distance measuring device of the terrestrial laser scanner at Kyviškès Calibration Baseline}

Calibration of the distance measuring device of the terrestrial laser scanner Leica Scanstation C10 was also performed at Kyviškès Calibration Baseline. This base consists of 6 pillars erected in a straight line with the distance between the first and the last pillar amounting to $1320 \mathrm{~m}$. Distances between the inner pillars are as follow: $1-2-100 \mathrm{~m}, 2-3-$ $260 \mathrm{~m}, 3-4-760 \mathrm{~m}, 4-5-180 \mathrm{~m}, 5-6-20 \mathrm{~m}$ (Jokela et al. 2002; Buga et al. 2008, 2011). During the calibration procedure, measurements of five different sectors of the calibration base were performed. The longest chosen distance amounted to 260 metres, i.e. did not exceed the maximal possible range of the terrestrial laser scanner. The measurements were performed between pillars $1-2 ; 2-3 ; 4-5 ; 4-6$ and



Fig. 3. Target scanned at Kyviškès calibration baseline

5-6. Laser scanner and targets were force-centred on the pillars (Fig. 3).

The calibration results are presented in Table 2.

As Table 2 provides, systematic errors change from $-16.9 \mathrm{~mm}$ to $3.7 \mathrm{~mm}$ and the constant $R$ of the terrestrial laser scanner is equal to $-8.5 \mathrm{~mm}$. The standard deviation of systematic errors change from $0.00 \mathrm{~mm}$ to $0.5 \mathrm{~mm}$ and the standard uncertainty of the mean systematic error value has a range from $0.0 \mathrm{~mm}$ to $0.1 \mathrm{~mm}$. A noticeable increase of the systematic error values could be observed in distances above $100 \mathrm{~m}$. Systematic error values are shown in Figure 4.

As the analysis of calculated distance measurement accuracies suggests, the systematic error tends to linearly increase with growing distance. For distances up to 100 metres, this error does not exceed $3.7 \mathrm{~mm}$ and, therefore, conforms to the technical specification of the investigated laser scanner, i.e. $4 \mathrm{~mm} / 50 \mathrm{~m}$. 
Table 2. Final results of calibration parameters pertaining to the distance measuring device of the laser scanner based on the calibration at Kyviškès Calibration Baseline

\begin{tabular}{|c|c|c|c|c|c|}
\hline $\begin{array}{c}\text { Segment } \\
\text { number }\end{array}$ & $\begin{array}{c}\text { Reference } \\
\text { distance, } \mathrm{m}\end{array}$ & $\begin{array}{c}\text { Mean measured } \\
\text { distance, } \mathrm{m}\end{array}$ & $\begin{array}{c}\text { Systematic error } \\
\text { of distances, } \mathrm{mm}\end{array}$ & $\begin{array}{c}\text { Standard deviation of } \\
\text { systematic error, mm }\end{array}$ & $\begin{array}{c}\text { Standard uncertainty } \\
\text { of mean systematic } \\
\text { error value, mm }\end{array}$ \\
\hline 1 & 20.0102 & 20.0095 & 0.7 & 0.0 & 0.0 \\
\hline 2 & 100.1632 & 100.1595 & 3.7 & 0.2 & 0.1 \\
\hline 3 & 180.0930 & 180.1070 & -14.0 & 0.4 & 0.1 \\
\hline 4 & 200.1032 & 200.1191 & -15.9 & 0.5 & 0.1 \\
\hline 5 & 260.0118 & 260.0287 & -16.9 & & 0.1 \\
\hline & & & $R=-8.5$ & & \\
\hline
\end{tabular}

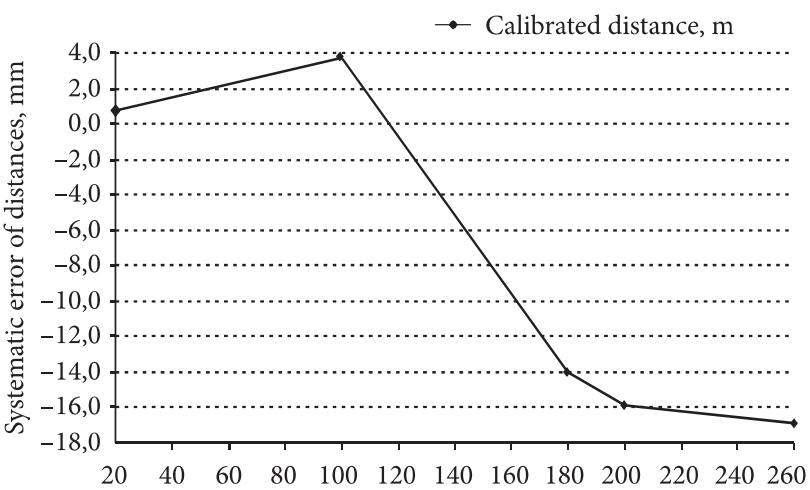

Fig. 4. Graphical representation of systematic errors of the terrestrial laser scanner distance measuring device based on the calibration at Kyviškès Calibration Baseline

\section{Calibration of the horizontal angle measuring device of the terrestrial laser scanner}

Calibration of the horizontal angle measuring device of the terrestrial laser scanner Leica Scanstation C10 was also performed at Kyviškès Calibration Baseline. The experiment was carried out by placing targets on pillars 5 and 6 . The accuracy of horizontal angle measurement was estimated from three different scanner positions with different angles with respect to the mentioned targets. Measured distances were corrected for systematic errors as described in the previous chapter. Based on trigonometric formulas, the comparison of measured and known (reference) horizontal angles was performed.

The measured angle between TLS and targets can be estimated by applying the coordinates of the targets and scanner:

$$
\beta_{i}=\operatorname{arctg}\left(\frac{Y_{K_{i}}-Y_{I_{i}}}{X_{K_{i}}-X_{I_{i}}}\right)-\operatorname{arctg}\left(\frac{Y_{I_{i}}-Y_{I_{i}}}{X_{J_{i}}-X_{I_{i}}}\right),
$$

here $X_{I_{i}}$ and $Y_{I_{i}}$ - coordinates of the scanner position, $X_{K_{i}}, Y_{K_{i}}, X_{J_{i}}$ and $Y_{J_{i}}$ - coordinates of the targets. The elements of the formulae (2) are shown in Figure 5.

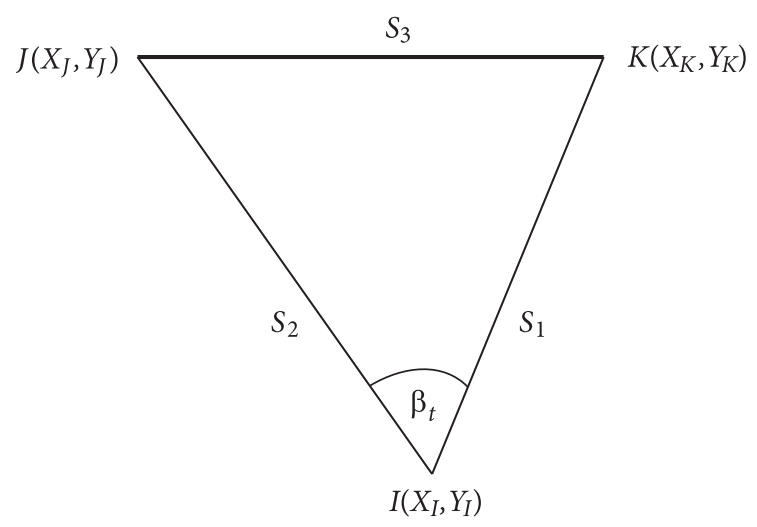

Fig. 5. Scheme for determination of the horizontal angle measured by TLS

The well-known cosine formulae were used to calculate value of the angle $\beta$ :

$$
S_{3}^{2}=S_{1}^{2}+S_{2}^{2}-2 S_{1} S_{2} \cos (\beta)
$$

and

$$
\beta_{t}=\arccos \frac{S_{1}^{2}+S_{2}^{2}-S_{3}^{2}}{2 S_{1} S_{2}} .
$$

The above formulae (4) should be used two times in carrying out the calibration process. The first time they should be used when the measured angle $\beta_{i}$ is calculated from laser scanner data (coordinates). And the next time the formulae (4) should be used for reference or real angle determination from the known reference distance $S_{3}$ and measured corrected distances $S_{1}$ and $S_{2}$.

Calibration results of the horizontal angle measuring device are presented in Table 3.

As Table 3 provides, systematic errors vary from $-3.5^{\prime \prime}$ to $0.6^{\prime \prime}$ depending on the angle sharpness. The angular constant of the terrestrial laser scanner is equal to $A=-1.3^{\prime \prime}$. The standard deviation of systematic errors varies from 2.1" to 5.1" and the standard uncertainty of the mean systematic error value has a range from $0.9^{\prime \prime}$ to $2.1^{\prime \prime}$. 
Table 3. Final results pertaining to calibration parameters of the horizontal measuring device of the laser scanner based on the calibration at Kyviškes calibration baseline

\begin{tabular}{|c|c|c|c|c|c|c|c|c|c|}
\hline $\begin{array}{c}\text { Mea- } \\
\text { sured } \\
\text { angle }\end{array}$ & \multicolumn{3}{|c|}{$\begin{array}{c}\text { Mean values of the } \\
\text { measured angle } \\
\text { o } \prime^{\prime \prime}\end{array}$} & \multicolumn{2}{|c|}{$\begin{array}{c}\text { Reference angle } \\
\text { o }, "\end{array}$} & $\begin{array}{c}\text { Angle } \\
\text { systematic error } \\
\prime \prime\end{array}$ & $\begin{array}{c}\text { Standard deviation } \\
\text { of systematic error } \\
\prime \prime\end{array}$ & $\begin{array}{c}\text { Standard uncertainty of } \\
\text { mean systematic error value } \\
\text { " }\end{array}$ \\
\hline 1 & 17 & 40 & 3.4 & 17 & 40 & 4.0 & 0.6 & 2.6 & 1.0 \\
\hline 2 & 26 & 8 & 32.4 & 26 & 8 & 31.4 & -1.0 & 5.1 & 2.1 \\
\hline 3 & 49 & 19 & 30.2 & 49 & 19 & 26.7 & -3.5 & 2.1 & 0.9 \\
\hline & & & & & & & $A=-1.3$ & & \\
\hline
\end{tabular}

\section{Conclusions}

The calibration method of the horizontal angle measuring device is proposed. It is based on placing the scanner in front of the calibration base reference line and measuring the angle in front of this line. The reference value of this angle is obtained from the lines of a triangle applying cosine formulae.

It is estimated that the accuracy of the investigated scanner distance measuring device is noticeably (from $\sim 4 \mathrm{~mm}$ to $\sim 14 \mathrm{~mm}$ ) decreases for the distances more than 100 metres. It is necessary to perform more tests with several scanners in order to determine whether it is a constructive defect or a random scanner deficiency.

The accuracy parameters of the investigated laser scanner Leica Scanstation C10 correspond with the accuracy criteria specified in the scanner technical specification.

\section{References}

Bae, K. H.; Lichti, D. D. 2007. On site self-calibration using planar features for terrestrial laser scanners, International Archives of Photogrammetry, Remote Sensing and Spatial Information Sciences, vol. 36 (Part 3/W52): 14-19.

Buga, A.; Jokela, J.; Putrimas, R. 2008. Traceability, stability and use of the Kyviskes calibration baseline - the first 10 years, in Proc. of the 7th International Conference Environmental Engineering, 22-23 May, 2008, Vilnius. Vilnius: Technika, 1274-1280.

Buga, A.; Jokela, J.; Putrimas, R.; Zigmantiene, E. 2011. Analysis of EDM instruments calibration at the Kyviškès calibration baseline, in Proc. of the 8th International Conference Environmental Engineering, 19-20 May, 2011, Vilnius. Vilnius: Technika, 1301-1305.

Cheok, G. S.; Saidi, K. S.; Lytle, A. M. 2007. Evaluating a ranging protocol for 3D imaging systems, in 24th International Symposium on Automation \& Robotics in Construction, 19-21 September, 2007, Kochi, Kerala, India, 81-87.

Chow, J.; Lichti, D.; Teskey, B. 2010. Self-calibration of the Trimble (Mensi) GS200 Terrestrial Laser Scanner, in ISPRS Commission V Mid-Term Symposium "Close range Image Measurement Techniques”, 22-24 June, 2010, Newcastle upon Tyne, United Kingdom (in Press).
Dorninger, P.; Nothegger, C.; Pfeifer, N.; Mólnar, G. 2008. Onthe-job detection and correction of systematic cyclic distance measurement of terrestrial laser scanners, Journal of Applied Geodesy 2(4): 191-204.

http://dx.doi.org/10.1515/JAG.2008.022

Ingensand, H. 2006. Methodological aspects in terrestrial laserscanning technology, in Proceedings of the 3rd IAG Symposium of Geodesy for Geotechnical and Structural Engineering and 12th FIG Symposium on Deformation Measurements, 22-24 May, 2006, Baden, Austria, [CD].

Jokela, J.; Buga, A.; Putrimas, R. 2002. Analysis of repeated calibration of Kyviškees baseline, Geodezija ir kartografija [Geodesy and Cartography] 28(4): 37-41.

Lichti, D. D.; Franke, J. 2005. Self-calibration of the iQsun 880 laser scanner, in Optical 3-D measurement techniques VII, vol. 1. Vienna, Austria, 112-121.

Lichti, D. D.; Licht, M. G. 2006. Experience with terrestrial laser scanner modelling and accuracy assessment, The International Archives of the Photogrammetry, Remote Sensing and Spatial Information Sciences, vol. 36 (Part 5): 155-160.

Lichti, D. D. 2007. Error modelling, calibration and analysis of an AM-CW terrestrial laser scanner system, ISPRS Journal of Photogrammetry and Remote Sensing 61(5): 307-324. http://dx.doi.org/10.1016/j.isprsjprs.2006.10.004

Lichti, D. D. 2010. Terrestrial laser scanner self-calibration: correlation sources and their mitigation, ISPRS Journal of Photogrammetry and Remote Sensing 65(1): 93-102. http://dx.doi.org/10.1016/j.isprsjprs.2009.09.002

Parian, A. J.; Grün, A. 2005. Integrated laser scanner and intensity image calibration and accuracy assessment, The International Archives of the Photogrammetry, Remote Sensing and Spatial Information Sciences, vol. 36 (Part 3/ W19): 18-23.

Pfeifer, N.; Briese, C. 2007. Geometrical aspects of airborne laser scanning and terrestrial laser scanning, IAPRS, vol. 36 (Part 3/W52): 311-319.

Pfennigbauer, M.; Ullrich, A. 2010. Improving quality of laser scanning data acquisition through calibrated amplitude and pulse deviation measurement, in SPIE Proceedings, vol. 7684: Laser Radar Technology and Applications XV. http://dx.doi.org/10.1117/12.849641.

Putrimas, R. 2010. Elektroninių tolimačių kalibravimo metodika ETKM-2010. IV leid. Vilniaus Gedimino technikos universitetas.

Reshetyuk, Y. 2006. Calibration of terrestrial laser scanners Callidus 1,1, Leica HDS 3000 and Leica HDS 2500, Survey Review 38(302): 703-713. http://dx.doi.org/10.1179/003962606780674763 
Reshetyuk, Y. 2009. Self-calibration and direct georeferencing in terrestrial laser scanning: Doctoral Thesis in Infrastructure, Royal Institute of Technology (KTH), Stockholm, Sweden [online], [cited June 2013]. Available from Internet: http:// kth,divaortal,org/smash/record,jsf?pid=diva2:139761

Reshetyuk, Y. 2010. A unified approach to self-calibration of terrestrial laser scanners, ISPRS Journal of Photogrammetry and Remote Sensing 65(5): 445-456.

http://dx.doi.org/10.1016/j.isprsjprs.2010.05.005

Salo, P.; Jokinen, O.; Kukko, A. 2008. On the calibration of the distance measuring component of a terrestrial laser scanner, in IAPRS (Ed.). Proceedings of the 21th ISPRS Congress, Silk Road for Information from Imagery, Vol. 37-B5, Beijing, China, 1067-1071.

Schneider, D.; Schwalbe, E. 2008. Integrated processing of terrestrial laser scanner data and fisheye-camera image data, The International Archives of the Photogrammetry, Remote Sensing and Spatial Information Sciences, vol. 37 (Part B5): 1037-1043.

Schneider, D. 2009. Calibration of a Riegl LMS-Z420i based on a multi-station adjustment and a geometric model with additional parameters, International Archives of Photogrammetry, Remote Sensing and Spatial Information Sciences, vol. 38 (Part 3/W8): 177-182.

Urtė ANTANAVIČIŪTĖ. Senior Data Operator. SE "GISCENTRAS”. Sèlių g. 66, LT-08109 Vilnius, Lithuania. $\mathrm{Ph}+37062065308$, e-mail: u.antanaviciute@gis-centras.lt

MSc at VGTU (2013).

Research interests: calibration of geodetic instruments, geodesy, terrestrial laser scanning, cartography.

Romuald OBUCHOVSKI. Doctor of Technological Sciences. Vilnius Gediminas Technical University. Dept of Geodesy and Cadastre, Sauletekio al. 11, LT-10223 Vilnius, Lithuania. Ph +370 5274 4703, Fax +370 5274 4705, e-mail: romuald.obuchovski@vgtu.lt $\mathrm{MSc}$ at VGTU (2002).

Research interests: geomagnetic field, gravity field, terrestrial laser scanning.
Eimuntas Kazimieras PARŠELIŪNAS. Professor, Doctor. Department of Geodesy and Cadastre, Vilnius Gediminas Technical University, Sauletekio al. 11, LT-10223 Vilnius, Lithuania. Ph +370 5274 4703, Fax +370 5274 4705, e-mail: eimis@vgtu.lt.

Doctor (1992). Habilitation procedure in 2008. Author of two teaching books and more than 50 scientific papers. Participated in many international conferences.

Research interests: graphs theory in geodesy, adjustment of geodetic networks, geoinformation systems.

M. G. Darius POPOVAS. Assistant Professor. Department of Geodesy and Cadastre, Vilnius Gediminas Technical University, Sauletekio al. 11, LT-10223 Vilnius, Lithuania. Ph +370 5274 4703, Fax+370 5274 4705, e-mail: darius.popovas@vgtu.lt.

Doctor of Technological Sciences (VGTU), 2011.

Research interests: terrestrial laser scanning, GNSS.

Dominykas ŠLIKAS. Doctoral student. Department of Geodesy and Cadastre, Vilnius Gediminas Technical University, Sauletekio al. 11, LT-10223 Vilnius, Lithuania. Ph +370 52744703 , Fax +370 5274 4705, e-mail: dominykas.slikas@vgtu.lt.

MSc at VGTU (2007).

Research interests: calibration of geodetic instruments, engineering geodesy, airborne and terrestrial laser scanning. 